\title{
Psychotropic medication - endocrine consequences
}

Authors: Georgiana Taujan, Diana Paun, Mihaela Nistor, Alina Dumitru, Adina Dragomir, Ruxandra Hristea, Constantin Dumitrache Gonadal and Adrenal Pathology Department, National Institute of Endrocrinology C. I. Parhon, Bucharest, Romania

\section{Introduction}

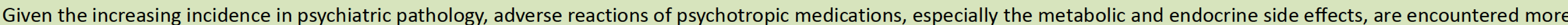
frequently in clinical practice.

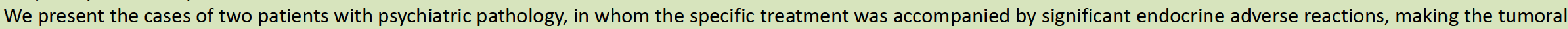
differential diagnosis very difficult.

\section{Case 1}

61 years old female presented to our clinic in 02.2015 for severe virilizing syndrome.

Patient's medical history

- reached menopause at 52 years old

- schizophrenia from the age 27 years, now treated with aripiprazole, valproate and diazepam

- hypertension from age 54, treated with $\beta$-blockers, ACE inhibitors and calcium blockers Clinical examination was within normal limits. Endocrinological examination revealed severe hirsutism installed progressively in recent years (apparently after initiation of valproate therapy) with androgenic alopecia

Paraclinical investigations:

- Hematological and biochemical test with normal values

- Hormonal tests:

- Normal TSH, freeT4

- Very high basal serum testosterone $(9.2 \mathrm{ng} / \mathrm{ml}, \mathrm{VN}<0.1-0.75 \mathrm{ng} / \mathrm{ml})$, with no response following $1 \mathrm{mg}$ dexamethasone suppression test

- Normal SHBG and DHEA-S

- $\mathrm{LH}, \mathrm{FSH}$, estradiol with inadequate values for menopause (suggestive for androgen hypersecretion in a woman at menopausal age)

- Serum cortisol with normal response in $1 \mathrm{mg}$ dexamethasone suppression test

- Normal plasma metanephrines and normetanephrines, aldosteron and hGC

\begin{tabular}{|c|c|c|c|c|c|}
\hline Test & \begin{tabular}{|l|l} 
Result \\
\end{tabular} & Reference range & Test & Result & Reference range \\
\hline \multirow[t]{2}{*}{ FSH } & \multirow[t]{2}{*}{7.77} & \multirow{2}{*}{$\begin{array}{l}\text { Follicular phase: } 3.85-8.78 \mathrm{IU} / \mathrm{mL} \\
\text { Luteal phase: } 1.79-5.12 \mathrm{mIU} / \mathrm{mL} \\
\text { Menopause: } 16.74-114 \mathrm{mIU} / \mathrm{mL}\end{array}$} & PRL & 12.56 & $\begin{array}{l}\text { Before menopause: } 3.34-26.72 \mathrm{ng} / \mathrm{ml} \\
\text { Menopause: } 2.74-19.64 \mathrm{ng} / \mathrm{ml}\end{array}$ \\
\hline & & & \multirow[t]{2}{*}{ Estradiol } & \multirow[t]{2}{*}{62} & Follicular phase:27-122 pg/ml \\
\hline \multirow[t]{2}{*}{ LH } & \multirow[t]{2}{*}{6.24} & \multirow{2}{*}{$\begin{array}{l}\text { Follicular phase: } 2.12-10.89 \mathrm{mlU} / \mathrm{mL} \\
\text { Ovulation surge: } 19.18-103.03 \mathrm{mlU} / \mathrm{mL} \\
\text { Luteal phase: } 1.20-12.86 \mathrm{mlU} / \mathrm{mL} \\
\text { Menopause: } 10.87-58.64 \mathrm{mlU} / \mathrm{mL}\end{array}$} & & & $\begin{array}{l}\text { Ovulation: } 95-433 \mathrm{pg} / \mathrm{m} \\
\text { Luteal phase: } 49-291 \mathrm{pg} / \mathrm{ml} \\
\text { Menopause: }<20.00-40 \mathrm{pg} / \mathrm{ml}\end{array}$ \\
\hline & & & TSH & 0.931 & $0.5-4.5 \mu \mathrm{UI} / \mathrm{ml}$ \\
\hline \multirow[t]{2}{*}{ SHBG } & \multirow[t]{2}{*}{55.5} & $26.1-110 \mathrm{nmol} / \mathrm{L}$ & fT4 & 12.4 & $12-22 \mathrm{pmol} / \mathrm{L}$ \\
\hline & & Menopause: $<14.1-68.9 \mathrm{nmol} / \mathrm{L}$ & \multirow{2}{*}{$\begin{array}{l}\text { Cortisol } \\
\text { (DXM 1mg } \\
\text { overnight) }\end{array}$} & & \multirow{2}{*}{$\begin{array}{l}7-10 \mathrm{am}: 6.7-22.6 \mu \mathrm{g} / \mathrm{dL} \\
4-8 \mathrm{pm}: 0-10 \mu \mathrm{g} / \mathrm{dL}\end{array}$} \\
\hline DHEA-S & 65.9 & $12-133 \mu \mathrm{g} / \mathrm{dL}$ & & & \\
\hline Testosterone & 9.2 & $<0.1-0.75 \mathrm{ng} / \mathrm{mL}$ & $\beta$-HCG & $<0.1$ & $<0.5-2.90 \mathrm{mUl} / \mathrm{mL}$ \\
\hline
\end{tabular}

Abdominal and pelvic CT scan with contrast: ovoid, homogeneous, well-defined mass in left adrenal gland, of $2.43 / 2.21 \mathrm{~cm}$, with $22 \mathrm{UH}-33 \mathrm{UH}$ spontaneous density and $30 \mathrm{UH}$ $37 \mathrm{UH}$ after contrast administration; two homogenous uterine masses of $2.9 / 2.4 / 2.8 \mathrm{~cm}$ and 2.6/1.1/1.5cm; without ovarian tumors.

Transvaginal ultrasound: two uterine fibroids measuring $33 / 29 \mathrm{mmm}$, respective $25 / 20 \mathrm{~mm}$; echogenic endometrium of $6 \mathrm{~mm}$ thickness; small ovaries, both with a cystic image of $15 / 12 \mathrm{~mm}$, respective $10 / 5 \mathrm{~mm}$.

Diagnostics:

- Ovarian hyperthecosis secondary to valproate treatment with severe virilizing syndrome

- Uterine fibroids

- Arterial hypertension stage II JNC 7

- Schizophrenia

Differential diagnostics:

- Androgen secreting tumor vs. pharmacological hyperandrogenism

- Adrenal androgen secreting tumor vs. ovarian androgen secreting tumor

- Essential hypertension vs. secondary hypertension

- Menopause vs. secondary amenorrhea

We considered the patient having valproate induced hyperandrogenism due to ovarian hyperthecosis because

$>$ Very high testosterone levels with low-normal value of DHEA-S

$>$ Lack of response of serum testosterone in the same test

$>$ Normal response of serum cortisol in $1 \mathrm{mg}$ DXM overnight test

$>C T$ characteristics of the adrenal mass and lack of ovarian tumors

$>$ Slow progressive evolution of the virilizing syndrome in the past 8 years, after

initiation of valproate treatment

We referred the patient to gynecologist for bilateral oophorectomy. The histopathological examination confirmed the diagnosis. The patient will be re-evaluated for the adrenal mass 6 months after the first CT scan.

Discussion: Although valproate therapy is frequently associated with ovarian polycystic syndrome in young women, in our case, the therapy was associated with ovarian hyperthecosis with severe virilizing syndrome in a postmenopausal woman, which is a rare but important cause of serum testosterone levels in the neoplastic range.

Case 2

24 years old female patient, presented in our clinic in 02.2015 for amenorheagalactorhea syndrome

Patient's medical history: recently diagnosed with depressive disorder, for which valproate and escitalopram treatment was started 5 months prior presentation.

Patient denies using any other drugs (including oral contraceptives) or taking dietary supplements in the last 2 years.

Clinical examination was within normal limits. Endocrinological examination revealed amenorrhea with bilateral galactorrhea, without headache or visual field disturbances, with no hirsutism or pathological striae.

Paraclinical investigations:

- Hematological and biochemical test with normal values (excluding hepatic or renal diseases)

- Negative pregnancy test

- Hormonal tests

- very high serum prolactin $(224 \mathrm{ng} / \mathrm{ml}, \mathrm{NV} 3-27 \mathrm{ng} / \mathrm{ml})$

- low-normal FSH and LH, with low serum estradio

- normal serum testosterone, SHBG, DHEA-S

- normal TSH, free T4

\begin{tabular}{ll|l|}
\hline Test & Result & Reference range \\
\hline PRL & 224 & $\begin{array}{l}\text { Before menopause: } 3.34-26.72 \mathrm{ng} / \mathrm{ml} \\
\text { Menopause: } 2.74-19.64 \mathrm{ng} / \mathrm{ml}\end{array}$ \\
\hline FSH & 4.26 & $\begin{array}{l}\text { Follicular phase: } 3.85-8.78 \mathrm{IU} / \mathrm{mL} \\
\text { Luteal phase: } 1.79-5.12 \mathrm{mlU} / \mathrm{mL} \\
\text { Menopause: } 16.74-114 \mathrm{mlU} / \mathrm{mL}\end{array}$ \\
\hline LH & 5.12 & $\begin{array}{l}\text { Follicular phase: } 2.12-10.89 \mathrm{mlU} / \mathrm{mL} \\
\text { Ovulation surge: } 19.18-103.03 \mathrm{mlU} / \mathrm{mL} \\
\text { Luteal phase: } 1.20-12.86 \mathrm{ml} / \mathrm{mL} \\
\text { Menopause: } 10.87-58.64 \mathrm{mlU} / \mathrm{mL}\end{array}$ \\
\hline Testosterone & 0.35 & $<0.1-0.75 \mathrm{ng} / \mathrm{mL}$
\end{tabular}

\begin{tabular}{|c|c|c|}
\hline Test & Result & Reference range \\
\hline SHBG & 36.4 & $\begin{array}{l}26.1-110 \mathrm{nmol} / \mathrm{L} \\
\text { Menopause: }<14.1-68.9 \mathrm{nmol} / \mathrm{L}\end{array}$ \\
\hline DHEA-S & 27.8 & $12-133 \mu \mathrm{g} / \mathrm{dL}$ \\
\hline Estradiol & $<20$ & $\begin{array}{l}\text { Follicular phase: } 27-122 \mathrm{pg} / \mathrm{ml} \\
\text { Ovulation: } 95-433 \mathrm{pg} / \mathrm{ml} \\
\text { Luteal phase: } 49-291 \mathrm{pg} / \mathrm{ml} \\
\text { Menopause: }<20.00-40 \mathrm{pg} / \mathrm{ml}\end{array}$ \\
\hline TSH & 1.27 & $0.5-4.5 \mu \mathrm{Ul} / \mathrm{ml}$ \\
\hline fT4 & 17.08 & $12-22 \mathrm{pmol} / \mathrm{L}$ \\
\hline$\beta$-HCG & $<0.1$ & $<0.5-2.90 \mathrm{mUl} / \mathrm{mL}$ \\
\hline
\end{tabular}

Pituitary CT scan revealed a normal sized pituitary gland with left sided small hypoattenuating nodule, with low enhancement after the contrast administration, measuring $0.4 / 0.4 \mathrm{~cm}$, with no displacement of the pituitary stalk

Diagnostics

- Pharmacological hyperprolactinemia

- Pituitary microadenoma

- Depressive disorder treated with valproate and SSRI

Differential diagnostics

- Tumoral vs pharmacological hyperprolactinemia

- Secondary amenorrhea vs premature ovarian failure

We referred the patient to the psychiatrist for evaluation of the depressive disorder treatment. Soon after excluding escitalopram, the patient reported remission of the galactorrhea and resuming rhythmic menstrual cycles.

This patient will also be re-evaluated 6 months after the first pituitary CT scan, in order to determine the evolution of the pituitary incidentaloma.

Discussions: SSRIs are considered the most common cause of pharmacological hyperprolactinemia; most frequently reported are sertraline, fluoxetine and paroxetine. Escitalopram is one of the most popular new generation SSRI and is indicated as firstline therapy in the treatment of depression. Escitalopram-associated hyperprolactinemia is considered a rare adverse reaction, with only a few reports in the literature.

\section{Conclusion}

In both cases, CT scans revealed incidentalomas (adrenal, respective pituitary) rising important issues regarding differential diagnostics.

Although endocrine side effects of psychotropic therapy are not life threatening and are less frequent than neurological side effects, such as sedation, extrapyramidal syndrome and cholinergic disorders, recognizing and correcting them (by changing the therapeutic agent) is the key to a successful therapy and ensures patient compliance.

References:

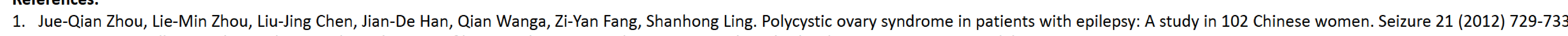

2. Daria La Torre, Alberto Falorni. Pharmacological causes of hyperprolactinemia. Therapeutics and Medical Risk Management 2007:3 (5) 929-951

3. Harold E. Carlson, Christoph U. Correll. Adverse effects of antipsychotics and mood stabilizers. Psychiatric Times (www.psychiatrictimes.com)

4. Se-Hoon Shim, Yeon-Jeong Lee, Eun-Chan Lee. A case of galactorrhea associated with escitalopram. Psychiatry Invest 2009;6:230-232.

5. Liana Dehelean, Pompilia Dehelean, Daniela Jitaru, Elena Stefan, Claudia Vasilian. Psychotropic medication and the endocrine system. Romanian Journal of Psychiatry, vol. XII, No. 4, 2010

6. Jouko Isoja rvi. Disorders of reproduction in patients with epilepsy: Antiepileptic drug related mechanisms. Seizure (2008) 17, 111-119 